\title{
The blood of healthy individuals exhibits CD8 $T$ cells with a highly altered TCR VB repertoire but with an unmodified phenotype
}

\author{
Nicolas Degauque ${ }^{1,2^{*}}$, Françoise Boeffard ${ }^{1,2}$, Yohann Foucher ${ }^{1,2,3}$, Caroline Ballet ${ }^{1,2}$, Jean-Paul Soulillou ${ }^{1,2}$, \\ Sophie Brouard ${ }^{1,2}$
}

From 6th European Workshop on Immune-Mediated Inflammatory Diseases

Nice, France. 23-25 November 2011

CD8 T cell clonal expansions (TCE) have been observed in elderly, healthy individuals as well in old mice, and have been associated with the ageing process. Both chronic latent and non-persistent viral infections have been proposed to drive the development of distinct non-functional and functional TCE respectively. Biases in TCR V $\beta$ repertoire diversity are also recurrently observed in patients that have undergone strong immune challenge, and are preferentially observed in the CD8 compartment. Healthy adults can also exhibit CD8 $\mathrm{T}$ cells with strong alterations of their CDR3 length distribution. Surprisingly, no specific investigations have been conducted to analyze the CD8 $\mathrm{T}$ cell repertoire in normal adults, to determine if such alterations in TCR V $\beta$ repertoire share the features of TCE. In this study, we characterized the phenotype and function of the CD8 population in healthy individuals of 25-52 years of age. All but one of the EBV-positive HLA-B8 healthy volunteers that were studied were CMVnegative. Using a specific unsupervised statistical method, we identified V $\beta$ families with altered CDR3 length distribution and increased TCR V $\beta /$ HPRT transcript ratios in all individuals tested. The increase in TCR V $\beta /$ HPRT transcript ratio was more frequently associated with an increase in the percentage of the corresponding $V \beta^{+}$ $\mathrm{T}$ cells than with an absence of modification of their percentage. However, in contrast with the previously described TCE, these $\mathrm{CD}^{+} \mathrm{T}$ cells were not preferentially found in the memory CD8 subset, they exhibited normal effector functions (cytokine secretion and cytotoxic molecule expression) and they were not reactive to a pool of EBV/CMV/Flu virus peptides. Taken together, the

IINSERM, UMR643, Nantes, France

Full list of author information is available at the end of the article combined analysis of transcripts and proteins of the TCR $\mathrm{V} \beta$ repertoire led to the identification of different types of $\mathrm{CD} 8^{+} \mathrm{T}$ cell clone expansion or contraction in healthy individuals, a situation that appears more complex than previously described in aged individuals.

\section{Author details}

'INSERM, UMR643, Nantes, France. ${ }^{2}$ Université de Nantes, Faculté de Médecine, Nantes, France. ${ }^{3}$ INSERM, EA 4275, Nantes, France.

Published: 23 November 2011

doi:10.1186/1479-5876-9-S2-P4

Cite this article as: Degauque et al:: The blood of healthy individuals exhibits CD8 T cells with a highly altered TCR VB repertoire but with an unmodified phenotype. Journal of Translational Medicine 2011 9(Suppl 2): P4.

Submit your next manuscript to BioMed Central and take full advantage of:

- Convenient online submission

- Thorough peer review

- No space constraints or color figure charges

- Immediate publication on acceptance

- Inclusion in PubMed, CAS, Scopus and Google Scholar

- Research which is freely available for redistribution

\section{() Biomed Central}

(c) 2011 Degauque et al; licensee BioMed Central Ltd. This is an open access article distributed under the terms of the Creative Commons Attribution License (http://creativecommons.org/licenses/by/2.0), which permits unrestricted use, distribution, and reproduction in any medium, provided the original work is properly cited. 